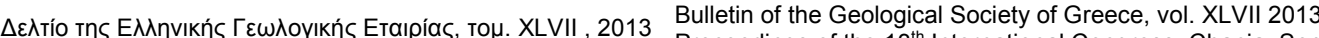
Proceedings of the $13^{\text {th }}$ International Congress, Chania, Sept.

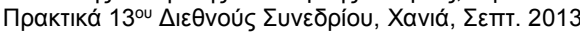
2013

\title{
CHARACTERIZATION OF SITE CONDITIONS IN GREECE FOR REALISTIC SEISMIC GROUND MOTION SIMULATIONS: PILOT APPLICATION IN URBAN AREAS
}

\author{
Kiratzi A. ${ }^{1}$, Klimis N. ${ }^{2}$, Theodoulidis $\mathrm{N} .^{3}$, Margaris $\mathrm{V} .^{3}$, Makra K. ${ }^{3}$, \\ Christaras B. ${ }^{1}$, Chatzipetros A. ${ }^{1}$, Papathanassiou G. ${ }^{1}$, Savvaidis A. ${ }^{3}$, Pavlides \\ Sp. ${ }^{1}$, Roumelioti Z. ${ }^{4}$, Sapountzi L. ${ }^{1}$, Diamantis I. $^{2}$, Lazaridis Th. ${ }^{2}$, Petala E. ${ }^{2}$ \\ and Mimidis $\mathrm{K.}^{2}$ \\ ${ }^{1}$ Aristotle University of Thessaloniki, School of Geology, kiratzi@geo.auth.gr, \\ christar@geo.auth.gr,ac@geo.auth.gr,gpapatha@auth.gr,stavsapountzi@yahoo.gr, \\ pavlides@geo.auth.gr \\ ${ }^{2}$ Democritus University of Thrace, Department of Civil Engineering,nklimis@civil.duth.gr, \\ jdiam@civil.duth.gr,theo.laza@gmail.com,epetala@civil.duth.gr,komimidi@civil.duth.gr \\ ${ }^{3}$ Institute of Engineering Seismology \& Earthquake Engineering, Thessaloniki, ntheo@itsak.gr, \\ margaris@itsak.gr,alexandros@itsak.gr,makra@itsak.gr \\ ${ }^{4}$ Aristotle University of Thessaloniki, Department of Civil Engineering, zroum@auth.gr
}

\begin{abstract}
We present the structure and first results of the "Thales" project on site classification in Greece. The aim of the project is twofold: to develop and present a methodology for the characterization and classification of site conditions based on their geological, geomorphological and geophysical characteristics and to apply the proposed methodology to case studies in Greece, including the urban areas of Xanthi, Edessa and Grevena. In particular, the units described on a surficial geological map will be correlated to shear-wave velocity data, corresponding to the upper $30 \mathrm{~m}$ (Vs30) of the soil column, aiming to produce first order maps to help practitioners and provide the tools to realistically predict ground motions triggered by an earthquake. The classification will be based on information provided by borehole logs, where velocity profiles were measured and will be validated using the three case studies. The outcome of the project will be usable by national agencies and decision makers for urban planning.

Key words: site characterization, surface geology, earthquake, $V_{30}$.
\end{abstract}

\section{Пєрі́ $\eta \psi \eta$}

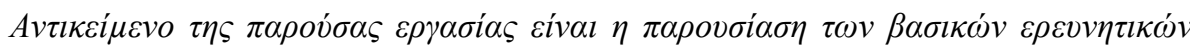

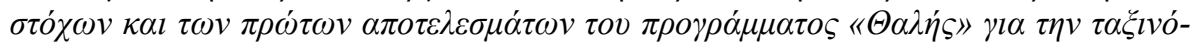

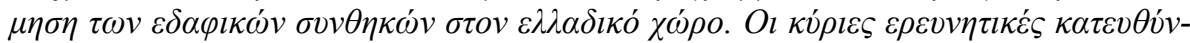

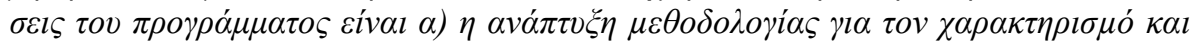

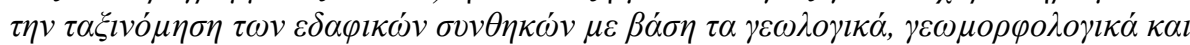

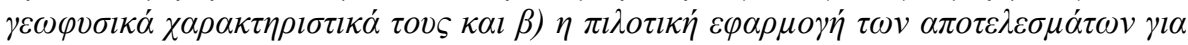

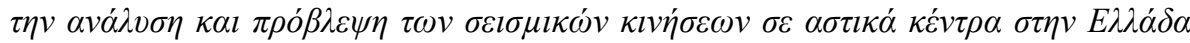




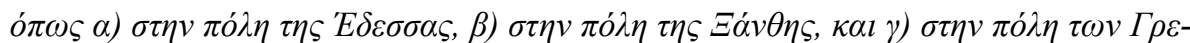

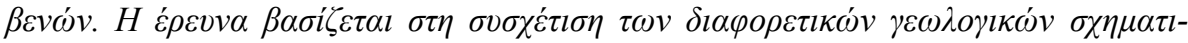

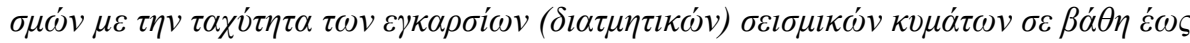

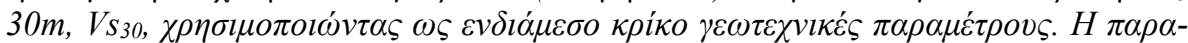

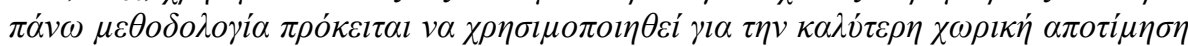

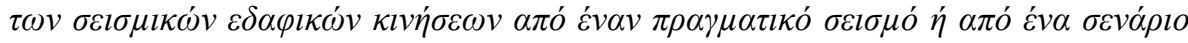

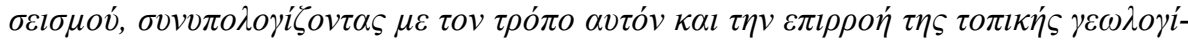

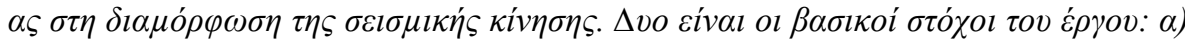

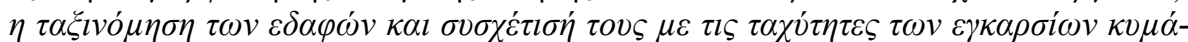

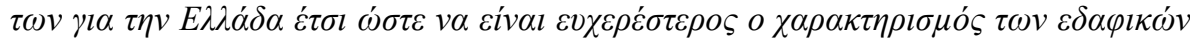

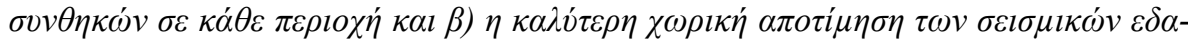

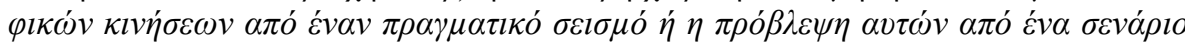

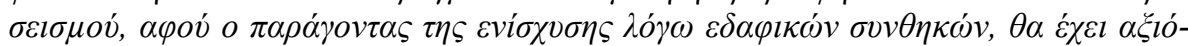
$\pi \iota \sigma \tau \alpha \sigma v v v \pi \circ \lambda o \gamma l \sigma \tau \varepsilon i$.

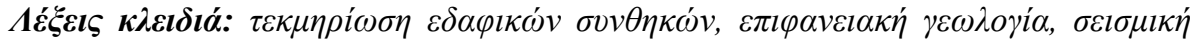
$\varepsilon \delta \alpha \varphi \imath \kappa \eta \dot{~ \kappa i ́ v \eta \sigma \eta, ~} V_{S 30}$

\section{Introduction}

Consideration of site conditions is a vital step in analyzing and predicting earthquake ground motion in order to estimate structural failure in urban areas endangered by large or even moderate magnitude earthquakes. It is well known from historical reports and post-earthquake reconnaissance field surveys that damage is usually greater at sites lying on soils than on rocks. Characteristic examples of site amplification is the 1985 Michoacán earthquake (Mexico) that induced severe structural damage to 10 and 20-stories buildings in Mexico City, at an epicentral distance of more than $400 \mathrm{~km}$ and the 1989 Loma Prieta earthquake that caused serious damage to structures built on non-engineered fill materials at the marina district of San Francisco and at the city of Oakland where structures were built on alluvial deposits (Wills et al., 2000).

The outcome of numerous studies regarding the factors that play an important role to site amplification is that soils modify seismic waves in at least three ways: generating reflected, refracted and/or diffracted waves at velocity discontinuities (Olsen and Archuleta, 1996), scattering the incoming wave as it encounters inhomogeneity within the soil (Zeng, 1993) and increasing the amplitude of the incoming wave in soils that are less tightly packed (Joyner and Boore, 1988; Borcherdt, 1994).

A widely used method for assessing site amplification is based on the evaluation of shear-wave velocity in the shallow subsurface. In particular, Borcherdt et al. (1991) showed that the shear wave velocity averaged over the upper $30 \mathrm{~m}\left(\mathrm{Vs}_{30}\right)$ can be correlated to the amplification of ground motions. The evaluation of the $\mathrm{Vs}_{30}$ can be achieved using the equation:

\section{Equation 1 - Formula for evaluating the Vs30}

$$
\mathrm{V}_{\mathrm{S} 30}=\frac{30}{\sum_{\mathrm{i}} \frac{\mathrm{h}_{\mathrm{i}}}{\mathrm{V}_{\mathrm{i}}}}
$$

where $h_{i}$ is the thickness of the $i_{\text {th }}$ layer in the upper $30 \mathrm{~m}$ of the soil column and $V_{i}$ the shear-wave velocity within it.

The importance of site amplification has been recognized and prompted strong efforts to map site conditions at regional scales (Holzer et al., 2005). Such maps are useful both for code applications and input to earthquake loss models.

XLVII, No $3-1149$ 
Initially, Joyner et al. (1981) proposed that the velocity to a depth equal to one quarter wavelength of the period of interest could represent the site conditions. They used quaternary mapping units and assigned a mean shear-wave velocity to each geological unit within the studied area. A few years later, Borcherdt et al. (1991) proposed a map that grouped the geologic units in San Francisco into four shear-wave velocity classes. Similar methodology was used by Park and Elrick (1998) in order to classify the geological units in southern California. The outcome of their study is the grouping of geological units into eight units with similar $\mathrm{Vs}_{30}$ values.

At the same period, the classification suggested by National Earthquake Hazards Reduction Program was incorporated in the building code in the United States of America (Building Seismic Safety Council - BSSC, 1995; 2001). This classification grouped soil and rock units into five categories (Table 1) based on the $\mathrm{Vs}_{30}$ values of Dobry et al. (2000).

Table 1 - Classification of sites adopted by the Building Seismic Safety Council of U.S.A (BSS C, 2001).

\begin{tabular}{|l|l|l|}
\hline Site class & Vs30 $(\mathbf{m} / \mathbf{s e c})$ & Geotechnical description \\
\hline A & $>1500$ & Hard rock \\
\hline B & $760 \leq \mathrm{VS}_{30} \leq 1500$ & rock \\
\hline C & $360 \leq \mathrm{VS}_{30} \leq 760$ & Very dense soil and soft rock \\
\hline D & $180 \leq \mathrm{VS}_{30} \leq 360$ & Stiff soil \\
\hline E & $<180$ & Soft soil \\
\hline
\end{tabular}

During the last decade, mapping of site conditions generally follows this model and the proposed classifications of geological units are based on the shear-wave velocity on the upper $30 \mathrm{~m}$. Wills et al. (2000) attempted to group geological formations according to $\mathrm{V}_{\mathrm{s}_{30}}$ in seven classes. In particular, they grouped geological units of similar age and properties and then assigned them to shear wave velocities groups (Wills et al., 2000).

Wills and Clahan (2006) developed a map of geological units that can be distinguished by their shear-wave velocity. In order to develop this map, they used data regarding the age as well as the properties of the geological units and their depositional environment (Figure 1).

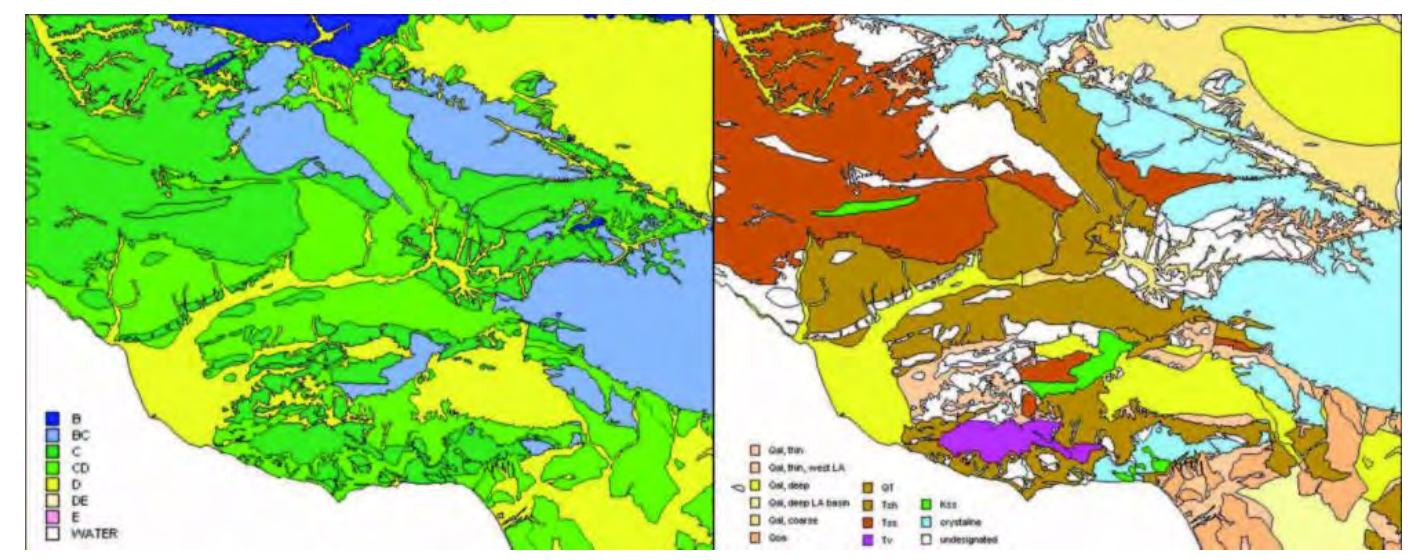

Figure 1 - Preliminary site-conditions map of California (Wills et al., 2000) and geological map based on shear-wave velocities categories on the right (Wills and Clahan, 2006). 
Furthermore, Holzer et al. (2005) investigated the correlation of Vs 30 -geology by taking into account the impact of the thickness of shallow geologic units and local measurements of Vs. They developed a map on 1:24.000 scale, based on in-situ $\mathrm{S}_{\mathrm{CPT}}$ data.

Recently, both Eurocode8 (EC8, CEN 2004) in Europe and the International Building Code (ICC, 2012) in USA adopted the same basic principles and approaches regarding soil classification (Pitilakis et al., 2012). In particular, the $\mathrm{Vs}_{30}$ parameter is used in EC8 along with $\mathrm{N}_{\mathrm{SPT}}$ blow count, plasticity index (PI) and un-drained shear strength, $C_{u}$ to define five soil types (A-E), while two extra special ground types (S1 and S2) are also proposed for soils that special attention should be paid (liquefaction, etc).

The aim of this project is to develop a classification of surficial geological units based on their geophysical and geomorphological characteristics that could be used for the development of simplified maps to be used by practitioners and for the estimation of the ground motions triggered by an earthquake.

Table 2 - Soil classification based on EC 8 (CEN, 2004).

\begin{tabular}{|c|c|c|c|c|}
\hline \multirow[b]{2}{*}{$\begin{array}{l}\text { Site } \\
\text { class }\end{array}$} & \multirow[b]{2}{*}{ Description } & \multicolumn{3}{|c|}{ Parameters } \\
\hline & & $\begin{array}{l}V_{S 30} \\
(\mathrm{~m} / \mathrm{s})\end{array}$ & $\begin{array}{l}\mathrm{N}_{\mathrm{SPT}} \\
\text { (blows/30cm) }\end{array}$ & $\begin{array}{l}\mathrm{C}_{\mathrm{u}} \\
(\mathrm{kPa})\end{array}$ \\
\hline A & $\begin{array}{l}\text { Rock or other rock-like geological } \\
\text { formation, including at most } 5 \mathrm{~m} \text { of weake } \\
\mathrm{r} \text { material at the surface }\end{array}$ & $>800$ & & \\
\hline B & $\begin{array}{l}\text { Deposits of very dense sand, gravel, or } \\
\text { very stiff clay, at least several tens of } \\
\text { meters in thickness, characterized by a } \\
\text { gradual increase of mechanical properties } \\
\text { with depth }\end{array}$ & $360-800$ & $>50$ & $>250$ \\
\hline $\mathrm{C}$ & $\begin{array}{l}\text { Deep deposits of dense or medium-dense } \\
\text { sand, gravel or stiff clay with thickness } \\
\text { from several tens to many hundreds of } \\
\text { meters }\end{array}$ & $180-360$ & $15-50$ & $70-250$ \\
\hline $\mathrm{D}$ & $\begin{array}{l}\text { Deposits of loose-to-medium cohesionless } \\
\text { soil (with or without some soft cohesive } \\
\text { layers), or of predominantly soft-to-firm } \\
\text { cohesive soil }\end{array}$ & $<180$ & $<15$ & $<70$ \\
\hline $\mathrm{E}$ & $\begin{array}{l}\text { A soil profile consisting of a surface } \\
\text { alluvium layer with Vs values of type C or } \\
\mathrm{D} \text { and thickness varying between about } 5 \\
\mathrm{~m} \text { and } 20 \mathrm{~m} \text {, underlain by stiffer material } \\
\text { with } \mathrm{Vs}>800 \mathrm{~m} / \mathrm{s}\end{array}$ & & & \\
\hline S1 & $\begin{array}{l}\text { Deposits consisting, or containing a layer } \\
\text { at least } 10 \mathrm{~m} \text { thick, of soft clays/silts with } \\
\text { a high plasticity index (PI>40) and high } \\
\text { water content }\end{array}$ & $<100$ & & $10-20$ \\
\hline S2 & $\begin{array}{l}\text { Deposits of liquefiable soils, of sensitive } \\
\text { clays, or any other soil profile not include } \\
\text { d in types A-E or S1 }\end{array}$ & & & \\
\hline
\end{tabular}




\section{Structure of the Project}

Recently reported earthquake-induced failures in Italy and Greece confirmed that the scale of structural damage depends on site conditions. In particular, the 1986 Kalamata and 1999 Athens events, regarding Greek territory, showed that one of the basic parameters influencing the severity of structural failures is the spatial distribution of alluvial deposits.

Taking into account the fact that the spatial distribution of sediments and particularly the alluvial ones is a basic factor for the amplification of seismic ground motion, it can be assumed that it is crucial to map and classify the quaternary geological units. This classification can be achieved by correlating the value of the shear-wave velocity on the upper $30 \mathrm{~m}\left(\mathrm{Vs}_{30}\right)$ with the type of deposits.

Thus, this project aims to provide a useful tool for the evaluation of site effects by establishing a relationship and proposing a relevant classification between geological formation of the Greek area and $\mathrm{Vs}_{30}$. This classification could be used by urban planners and decision makers for designing the extension of urban areas or in near real time seismological applications for seismic hazard and seismic impact assessment. In order to achieve this goal, the spatial distribution of quaternary deposits is going to be examined in conjunction with their physical and mechanical properties following widely-used methodologies for evaluating seismic ground motion. The main tasks of our project are outlined below:

- Initially, the geological units will be grouped using criteria related to the depositional process, material, age and physical properties.

- Afterwards, by taking into account published classifications and data provided by in-situ tests, shear-wave velocity values will be assigned to each group of geological units

- One of the most important tasks of the project is the geological field reconnaissance of suitable sites for field testing using SCPT seismic cone. These tests will be performed at sites specifically selected for their geological structure: formations would be homogenous or at least with clearly defined stratigraphy based on their granulometry (the classification will be the one proposed by the Unified Soil Classification System (USCS; http://www.astm.org/), (i.e. coarse grained or unconsolidated and fine grained or consolidated). The results of this task are expected to clarify the contacts between overlapping geological formations and define the proposed classification of the geological formations based on shear wave velocity. The methodology that will be followed is described in the following subtasks:

-Literature review and data extraction concerning homogenous geological formations from published 1:50,000 I.G.M.E. geological maps, papers, technical reports, etc.

-Fieldwork at selected sites for the reconnaissance of the geological structure and the characterization of the formations based on their sedimentation facies and age.

- An additional field task deals with surface geology and structure reconnaissance at sites where accelerographs have already been installed and ground motions records are available. In this way, the processes and the deposition environment of each formation will be clarified and they will be characterized and classified. The field work will consist of geological characterization of surface soil and rock formations based on the published 1:50,000 I.G.M.E. maps, papers, technical reports and field reconnaissance.

- A task will deal with the collection and evaluation of existing information regarding the extent of the geological formations at the selected sites, compilation of geological maps and geological profiles showing the structure, stratigraphic position and thickness of each formation. The methodology that will be followed for this objective consists of:

- Literature review on the surface geology of the selected sites based on the published 1:50,000 I.G.M.E. maps, papers, technical reports etc.

XLVII, No 3 - 1152 
Fieldwork at selected pilot sites in order to define the geological structure and, when possible, the basement outcrops.

- Characterization of the geological formations based on their depositional environment, age and, when possible, their granulometry, in order to comprehend the local geological conditions.

- Finally, having classified the geological units, a task will deal with the application of the proposed methodology to selected urban areas. In particular, the cities of Xanthi, Grevena and Edessa were selected as pilot areas due to their characteristic topography (Edessa) and/or their seismotectonics setting (Xanthi and Grevena). Single station ambient noise measurements as well as ambient noise array measurements are currently implemented within the aforementioned cities in order to determine selected soil dynamic properties of geologic surface layers. Finally, the new soil classification scheme will be validated/verified in simulations of recorded strong ground motion at specific points (i.e. those of permanently installed accelerographs) and if judged qualified, it will be incorporated in a methodology for the computation of shake maps from scenario earthquakes.

\section{Accomplished Tasks}

The initial task of this project was the collection of existing geological information and data provided in literature, maps and geotechnical boreholes concerning the urban areas of Edessa, Xanthi and Grevena.

The outcome of this research is a compilation of a database where data provided by more than 100 borings are employed (Figure 2). In particular, regarding the urban area of Xanthi, 60 geotechnical boreholes with NSPT measurements have been collected. The depth of the boreholes ranges from $1.9 \mathrm{~m}$ to $30 \mathrm{~m}$, whereas $33 \%$ of them were drilled down to $10 \mathrm{~m}$. In the area of Grevena, the review of published reports and articles resulted to the compilation of a database with 31 geotechnical boreholes that were mainly drilled within the city. The depth of the boreholes varied between $2 \mathrm{~m}$ and $20 \mathrm{~m}$, while the majority of the information (circa $68 \%$ ) is provided by boreholes of depth from $10 \mathrm{~m}$ to $15 \mathrm{~m}$. Finally, regarding the third pilot area (city of Edessa), data provided by 22 geotechnical boreholes in the city of Edessa were collected. Most of them were drilled before the 90's, during the construction of state buildings and their depth varies from 8 to $28 \mathrm{~m}$.

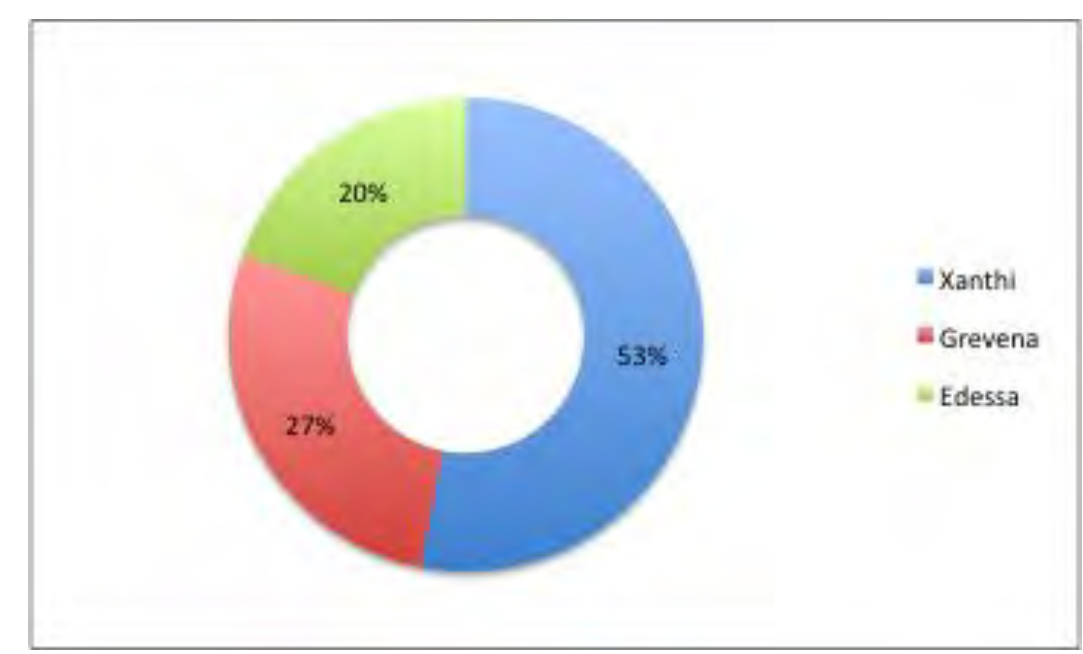

Figure 2 - Comparative presentation of the amount of borehole data collected for each of the three pilot areas (Xanthi, Grevena, and Edessa) as a percentage of the entire database that was created for the pilot studies.

$\underline{\text { XLVII, No } 3-1153}$ 
The collected data are organised in an excel database, where all basic information is presented in 25 columns (Figure 3 ). In particular, borehole ID, its location (coordinates), depth and water table level are employed in the first 6 columns followed by information on the upper and lower level of the geological units (per layer) and a relevant brief geological-geotechnical description based on $\mathrm{N}_{\text {SPT }}$ values and Atterberg limits (Liquid limit and Plasticity index) of the soil units. In addition, data provided by laboratory tests (e.g. grain size analysis) are also employed and used for the classification of the geological units according to USCS. Finally, 6 fields are used to include information regarding the recorded shear wave velocity Vs per unit, the average value of Vs on the upper $30 \mathrm{~m}$ and the relevant classification based on Eurocode 8.

\begin{tabular}{|c|c|c|c|c|c|c|c|c|}
\hline $\mathrm{J}$ & $\mathrm{K}$ & $\mathrm{L}$ & $M$ & $\mathrm{~N}$ & 0 & $\mathrm{P}$ & Q & $\mathrm{R}$ \\
\hline \multicolumn{3}{|c|}{$\begin{array}{c}\text { GRAIN SIZE ANALYSIS } \\
(\%)\end{array}$} & \multicolumn{2}{|c|}{$\begin{array}{l}\text { ATTERBERG } \\
\text { LIMITS }\end{array}$} & \multirow[t]{2}{*}{$\begin{array}{c}\text { U.S.C.S. } \\
\text { CLASSIFICATION }\end{array}$} & \multirow[t]{2}{*}{$\begin{array}{c}\text { SIMPLIFIED } \\
\text { CLASSIFICATION }\end{array}$} & \multirow[t]{2}{*}{$\mathrm{N}_{30}(\mathrm{SPT})$} & \multirow{2}{*}{$\begin{array}{c}\text { Depth of SPT } \\
(\mathrm{m})\end{array}$} \\
\hline Gravels (>No4) & Sand & Fines $(<\mathrm{No} 200)$ & $W_{L} \%$ & $\mathrm{PI} \%$ & & & & \\
\hline 3,5 & 88,5 & 8 & & & SM-SW & $S$ & 11 & 2,00 \\
\hline 2 & 80,5 & 17,5 & & & SM & $S$ & 45 & 4,00 \\
\hline 1 & 61 & 38 & & & $\mathrm{SC}$ & $S$ & 19 & 6,50 \\
\hline \multirow[t]{8}{*}{15} & 63,5 & 21,5 & & & SM & $\mathrm{S}$ & 18 & 8,00 \\
\hline & & & & & & & 21 & 10,00 \\
\hline & & & & & & & 20 & 12,50 \\
\hline & & & & & & & 20 & 14,50 \\
\hline & & & & & & & 30 & 16,50 \\
\hline & & & & & & & 42 & 18,50 \\
\hline & & & & & & & 24 & 21,00 \\
\hline & & & & & & & $>50 / 10 \mathrm{~cm}$ & 23,5 \\
\hline
\end{tabular}

Figure 3 - Part of the excel database designed and created to include all information necessary to proceed to the soil classification in Greece.

The single station ambient noise measurements were given priority for the city of Xanthi where detailed geological/geotechnical information is available. As a passive geophysical method it requires a preliminary stage of carefully selected sites before a dense mesh of measurements is accomplished throughout the city. For this purpose, two measurements were performed at the accelerograph stations and six in selected sites based on available geological maps. Each measurement had duration of 30 minutes and sensor's coupling was ground. Following the SESAME guidelines instructions (SESAME Project, 2004) the H/V spectral ratio method was calculated in order to define fundamental frequency and its corresponding amplification due to surface geologic layers.

Results of the analysis are shown in Figure 4. It is observed that a systematic "bump" of the H/V curve is apparent for frequencies less than $1.5 \mathrm{~Hz}$. Almost all sites do not show a clear $\mathrm{H} / \mathrm{V}$ fundamental peak but rather a broad one between $0.4 \mathrm{~Hz}$ to $1 . \mathrm{Hz}$. However, for the site 027 a clear fundamental frequency peak is apparent around $0.25 \mathrm{~Hz}$. Taking into account the preliminary results of the $\mathrm{H} / \mathrm{V}$ spectral ratio together with all available geological and geotechnical information for the city of Xanthi, a dense mesh of ambient noise measurements is going to be implemented. Based on the $\mathrm{H} / \mathrm{V}$ zonation of the city as well as on available geological information, ambient noise array for a few sites will be also performed in order to define $\mathrm{V}_{\mathrm{sz}}$ shear wave velocity values as a function of depth $\mathrm{z}$, at least for the upper 30 meters.

\section{Results - Discussion}

Although the "Thales" project is still in its beginning, we have managed to accomplish several important tasks i.e. the collection of geotechnical borehole data for the three pilot areas (Xanthi, Edessa and Grevena) and most importantly the design and implementation of a database that will host this data. This database is continuously growing with the addition of relevant geotechnical information from boreholes throughout the Greek mainland. Apart from the expected scientific results of the project, the database itself is a major deliverable to the scientific community.

XLVII. No 3 - 1154 


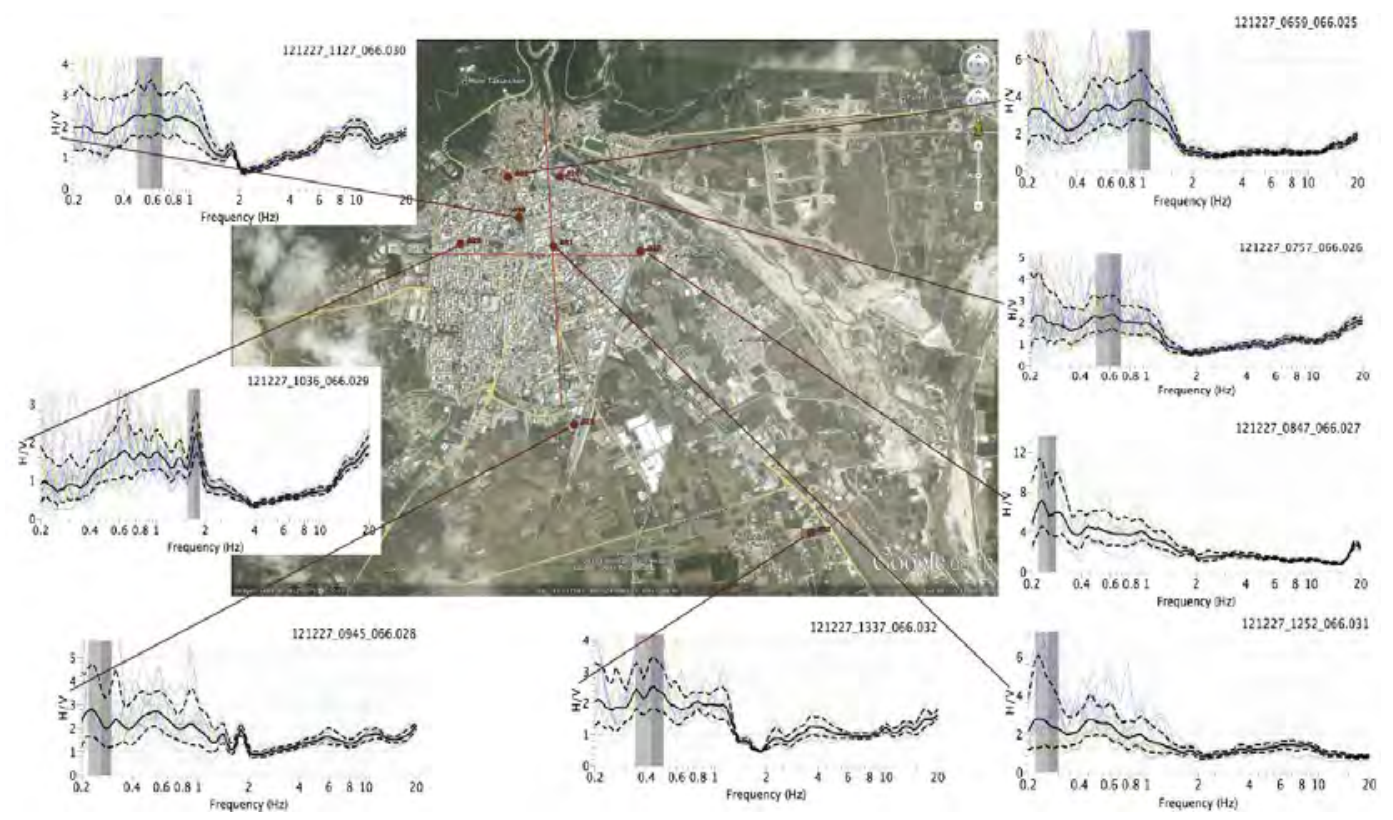

Figure 4 - H/V spectral ratio in selected sites of Xanthi, based on single station ambient noise measurements.

At present, the "Thales" project on site classification in Greece continues with the geological reconnaissance surveys at selected sites and field measurements to augment our geotechnical database and improve our knowledge on the relation between data at hand and surface geology.

\section{Acknowledgments}

This research has been co-financed by the European Union (European Social Fund - ESF) and Greek national funds through the Operational Program "Education and Lifelong Learning" of the National Strategic Reference Framework (NSRF) - Research Funding Program: "Thales". Investing in knowledge society through the European Social Fund.

\section{References}

Borcherdt R. D., Wentworth C. M., Janssen A., Fumal T. and Gibbs J. 1991. Methodology for predictive GIS mapping of special study zones for strong ground motion in the San Francisco Bay region, CA, Proc. Fourth Int. Cont. on Seismic Zonation, Earthquake Engineering Research Institute, Oakland, California, 545-552.

Borcherdt R. D. 1994. Estimates of site-dependent response spectra for design (methodology and justification), Earthquake Spectra, 10, 617-653.

Building Seismic Safety Council (BSSC) 1995. 1994 Edition, NEHRP Recommended Provisions for Seismic Regulations for New Buildings, FEMA 222A/223A, Vol. 1 (Provisions) and Vol. 2 (Commentary), developed for the Federal Emergency Management Agency, Washington, D.C.

Building Seismic Safety Council (BSSC) 2001. 2000 Edition, NEHRP Recommended Provisions for Seismic Regulations for New Buildings and Other Structures, FEMA-368,Part1 (Provisions): developed for the Federal Emergency Management Agency, Washington, D.C.

CEN (European Committee for Standardization) 2004. Eurocode 8: design of structures for earthquake resistance, part 1: general rules, seismic actions and rules for buildings. EN 1998$1: 2004$. Brussels, Belgium 
Dobry R., Borcherdt R. D., Crouse C. B., Idriss I. M., Joyner W. B., Martin G. R., Power M. S., Rinne E. E. and Seed R. B. 2000. New site coefficients and site classification system used in recent building code provisions, Earthquake Spectra, 16 (1), 41-68

Holzer T. L., Padovani A. C., Bennett M. J., Noce T. E. and Tinsley J. C. III 2005. Mapping V $\mathrm{s}_{\mathrm{s} 30}$ site classes, Earthquake Spectra, 21 (2), 353-370.

Joyner W.B., Warrick R.E. and Fumal T.B. 1981. The effect of Quaternary alluvium on strong ground motion in the Coyote Lake, California, earthquake of 1979, Bull. Seism. Soc. Am., $71,1333-1350$

Joyner W. B. and Boore,D. M. 1988. Measurement, characterization, and prediction of strong ground motion, Proc. Earthquake Engineering, \#38, Soil Dynamics II GT Div/ASCE, Park City, Utah, June 27-30, 1988.

ICC (International Code Council) 2012 International Building Code. International Code Council, Inc. www.iccsafe.org/Pages/default.aspx

Olsen K. B. and Archuleta R. J. 1996. Three-dimensional simulation of earthquakes on the Los Angeles fault system, Bull. Seism. Soc. Am., 86, 575-596.

Park S. and Elrick S. 1998. Predictions of shear-wave velocities in southern California using surface geology, Bull. Seism. Soc. Am., 88, 677- 685 .

Pitilakis K., Riga E. and Anastasiadis A. 2012. Design spectra and amplification factors for Eurocode 8, Bulletin of Earthquake Engineering, Vol 10(5), 1377-1400.

SESAME Project., 2004. Guidelines, Final Report, 2004; (http://sesame-fp5.obs.ujfgrenoble.fr/index.htm).

Wills C. J., Petersen M., Bryant W. A., Reichle M., Saucedo G. J., Tan S., Taylor G. and Treiman J. 2000. A Site-Conditions Map for California Based on Geology and Shear-Wave Velocity, Bull. Seism. Soc. Am., 90 (6B), S187-S208.

Wills C.J. and Clahan K.B. 2006. Developing a Map of Geologically Defined Site-Condition Categories for California, Bull. Seism. Soc. Am., 96(4A), 1483-1501.

Zeng Y. 1993. Theory of scattered $\mathrm{P}$ and $\mathrm{S}$ waves energy in a random isotropic scattering medium, Bull. Seism. Soc. Am., 83, 1264-1276. 